\title{
RISK MANAGEMENT DURING TIME OF FINANCIAL TURBULENCE: THE CASE OF SAUDI ARABIA AND OMAN
}

\author{
Ayman Zerban \\ College of Business Administration (University of Business and Technology, \\ Saudi Arabia) \\ Rafik Omar \\ School of Management (Cardiff Metropolitan University, UK) \\ Wadhah Zahir Salim Al Sibani \\ Sultan Qaboos University, Muscat, Oman.
}

Doi: 10.19044/elp.v2no1a4 URL:http://dx.doi.org/10.19044/elp.v2no1a4

\begin{abstract}
:
Risk and economic activities cannot be separated. Risk can be viewed from various levels such as investors, firms and country level also it has various types such as market, operational, and credit risk. In general risk is associated with the uncertainty about various events. The global financial crises created various doubts about the effectiveness of traditional risk management approaches. It seems that the relevance of risk management was lost. The global financial system failed to prevent the global crises and to minimize its impact. It becomes more apparent that risk sharing can be more fruitful than risk taking. Every country is trying to deal with financial shocks. The 2014-2015 crude oil prices have raised the risk of gulf countries heavily dependable on crude oil export revenues for development and financing expenditures. Saudi Arabia and Oman economies are greatly dependent on their oil and gas sector returns. In fact, reliance entirely on one industry to build economic development would be a serious risk, in case of falling prices or production capacity due to various reasons. The two countries deal with financial turbulence differently. What they did and are doing is the concern of this paper.
\end{abstract}

Keywords: Risk management, Saudi Arabia, Oman, Global financial crises

\section{Introduction}

The purpose of this paper is to highlights the efforts of two countriesSaudi Arabia and Oman- in managing financial risk during time of 
turbulence and financial shocks. Firstly, it explains a general shock which is global Financial Crises and how Saudi Arabia tried to mitigate it and control its impact. The Saudi Arabia Monetary Agency (SAMA) tried through various policies to manage risk and through its high reserves it was very successful. Secondly, a particular financial shock to Arab oil exporters and how Oman is trying to manage risk of decreasing oil prices. In contrast to Saudi Arabia, Oman tried to develop SMEs in order to diversify business sectors and tries to encourage an alternative economy less dependable on crude oil revenues for governmental financials. Due to various reasons, efforts in Oman up till the beginnings of 2015 were not successful- as in the case of Saudi Arabia during Global Financial Crises- in managing risk of decreasing crude oil prices.

The 2014-2015 crude oil prices decline has raised the risk of gulf countries heavily dependable on crude oil export revenues for development and financing expenditures. Systemic risk is the risk of collapse of an entire financial system or entire market, as opposed to risk associated with any one individual entity, group or component of a system, which can be contained without harming the whole system. It has many causes but it represent a shock that produces negative effects for most or all of the domestic economy or system. It could have effect on the entire banking, financial, or economic system, rather than just one or a few institutions. Kaufman (2000, p.14) states:

For countries, this may occur through direct trade linkages so that if country A experiences problems or a depreciation in its exchange rate that reduce its imports from country B, it causes B's aggregate income to decline, reducing its imports from country $\mathrm{C}$, and so on down the chain. What makes direct causation (chain reaction) systemic risk in financial sectors particularly frightening to many is both the lightning speed with which it is believed to occur and the perception that it can infect innocent as well as guilty parties, so that there is little or no protection against its damaging effects.

A prominent issue in the area of finance is how to measure and manage risk. Expected rate of return rate is not a one solid indivisible brick, in fact it is constructed form several factors that combined forms the interest rate as we know it today. A representative equation for any investor, depositor or even saver when making a decision concerning his money is the Capital Asset Pricing Model. The CAPM can be expressed by the following formula:

$$
\boldsymbol{K}_{e}=\boldsymbol{K}_{r f}+\left(\boldsymbol{K}_{m}-\boldsymbol{K}_{r f}\right) \boldsymbol{\beta}
$$

$\boldsymbol{K}_{\boldsymbol{e}}=$ expected rate of return on investment 
$\boldsymbol{K}_{\boldsymbol{r} \boldsymbol{f}}=$ rate of return on risk free

$\boldsymbol{K}_{\boldsymbol{m}}=$ market rate of return

$\boldsymbol{\beta}=$ risk factor of specific investment

In this equation we can clearly see that interest (or rate of return) required on any financial product or transaction is actually composed of three main parts: first, the risk-free part - a macro level decided by a government's central bank and over which individuals have no control; second, the market rate of return - a micro level determined by general market expectations of the rate and it is simply a build up over the risk-free for venture capitalists to risk their money in the market; third, the riskiness factor which justifies the high return of one product compared to the other based on the rule that the higher the risk, the higher the return (Mishkin, 2012 and Ingham, 2008). The equation of CAPM can be modified to include country risk as follows according to Numoski, (2012):

$$
\mathbf{E}(\mathbf{R})=\mathbf{R f}+\boldsymbol{\beta}(\mathbf{E R P m})+\mathbf{C R P}
$$

$\mathbf{E}(\mathbf{R})=$ required or expected rate of return for investing in an emerging market

$\mathbf{R f}=$ is the risk-free rate in a developed market (e.g. the USA)

$\boldsymbol{\beta}=$ is a firm's beta, or the beta of an equivalent project in a developed country (e.g. the USA)

$\mathbf{E R P m}=$ is the equity risk premium in a mature market (e.g. the USA) as the difference between the rate of return on the developed market (e.g. S\&P500) and the risk-free rate in a developed market (e.g. the USA), i.e. ERPm = $E(R m)-\mathrm{Rf}=$

$\mathbf{C R P}=$ is the country risk premium of an emerging country.

The rate of return in emerging markets is higher than developed markets due to higher risk. Numoski (2012, p.414-18) states:

The required rate of return is more difficult to assess in the case of emerging markets. Most academics agree that, in the required rate of return, the country risk must be rewarded with a country risk premium (CRP) over an equivalent investment in a developed country .... To multinational companies faced with a range of risks derived from factors closely related to a particular foreign country, broadly classified as financial, economic and political risk factors, it may seem unreasonable to invest abroad. In order to facilitate international trade and to promote their exports, many 
countries have established a state-backed specialized institution usually named a credit export agency. Their primary task is to provide country risk insurance to companies and the second is to assist their exporters through financial support and funding. Here, among the most famous we will mention ECGD (UK), Coface (France), Hermes (Germany), Sace (Italy), EDC (Canada), or Exim Bank (USA).AUMOS NAUMOSKIKI

Therefore the governmental intervention through encouragement of risk sharing according to Islamic finance principles will lead to the mitigation of the overall country risk through diversification of investments in physical assets. As according to Islamic finance guide lines that have been extensively studied by financial and economic scholars worldwide who have concluded that the general principles can be summarized as follows (Gait and Worthington, 2007):

(i) Prohibition of usury or excessive interest - riba;

(ii) Full disclosure of information in any contract or exchange and removal of any asymmetrical information in a contract - gharar;

(iii) Prohibition of financing and/or dealing in sinful/socially-irresponsible activities and commodities regarded as non-permitted (haram) under Islamic, such as gambling and the production of alcohol for consumption;

(iv) Business risk-sharing between capital provider (financier) and capital user (entrepreneur) in profits and losses;

(v) Materiality - a financial transaction needs to have a 'material finality', that is a direct or indirect link to a real economic transaction;

(vi) Prohibition of exploitation of any party to the transaction and promotion of justice and fair trade.

To this list, Rowey et al. (2006) added that capital should have a positive social and ethical impact and investors should not just consider profit. The point of prohibition of taking interest in itself enforces risk-sharing in project financing. Therefore, Islamic financiers can derive their profit either from fees or fixed charges and in partnerships share both profit and loss. Rowey et al. (2006) defined gharar more widely than selling items which you do not own, i.e. not only the full disclosure of contractual terms and conditions or full description of goods but also included maysir(gambling or speculation) which is also prohibited by Islamic jurisprudence.

Governments intervene directly or indirectly through for example the development of SMEs to develop an alternative economy less dependable on crude oil revenues. Accordingly we can use the principle of risk sharing, capital having social impacts and materiality of transaction (physical assets) 
to risk mitigation through government's programmers and policies and the nurture and encouragement of SMEs to develop a diverse healthy economy to control and manage risk. The paper proceeds as follows: section two highlights in general difference between Islamic finance and traditional finance, section three and four contrasted the role played by Saudi Arabia and Oman in managing country risk during time of turbulence. Section five is a conclusion to the paper.

\section{Islamic finance versus traditional finance in managing risk.}

The last decade of the $20^{\text {th }}$ century and the few years towards the beginnings of the $21^{\text {st }}$ century showed explosion in the financial shocks this magnified due to financial integration. Fundamental economic forces have led to increase competition in financial markets. Greater competition in turn has diminished the cost advantage banks have had in acquiring funds and has undercut their position in loan markets. As a result, traditional banking has lost profitability, and banks have begun to diversify into new activities that bring higher returns. The ability to securitize assets has made nonbank financial institutions even more formidable competitors for banks. Advances in information and data processing technology have enabled nonbank competitors to originate loans, transform these into marketable securities, and sell them to obtain more funding with which to make more loans. Computer technology has eroded the competitive advantage of banks by lowering transactions costs and enabling nonbank financial institutions to evaluate credit risk efficiently through the use of statistical methods. When credit risk can be evaluated using statistical techniques, as in the case of consumer and mortgage lending, banks no longer have an advantage in making loans (Zerban et al., 2012).

Khan and Ahmed (2001) differentiate between different types of risks exposed by financial institutions and pointed to their need to define business strategy in order to be able to control it. It is important to efficiently diversify unsystematic risk and reducing and transferring systematic risk. An effort is being made in the United States to develop a market for securitized small business loans as well. Before 1980, two U.S. banks, Citicorp and Bank America Corporation, were the largest banks in the world. In the 1990s, neither of these banks ranks among the top twenty. The problem is not limited to United States only but it is a worldwide epidemic as stated by (Edward and Mishkin, 1995, p.35)

French and British banks suffered from the worldwide collapse of real estate prices and from major failures of risky real estate projects funded by banks. Olympia and York's collapse is a prominent example. The loan-loss provisions of British and French banks, like those of U.S. 
banks, have risen in the 1990s. One result has been the massive bailout of Credit Lyonnais by the French government in March 1995. Even in countries with healthy banking systems, such as Switzerland and Germany, some banks have run into trouble. Regional banks in Switzerland failed, and Germany's BfG Bank suffered huge losses (DM 1.1 billion) in 1992 and needed a capital infusion from its parent company, Credit Lyonnais. Thus, fundamental forces not limited to the United States have caused a decline in the profitability of traditional banking throughout the world and have created an incentive for banks to expand into new activities and take additional risks.

Much of the controversy surrounding banks efforts to diversify into off-balance-sheet activities has centered on the increasing role of banks in derivatives markets. Large banks, in particular, have moved aggressively to become worldwide dealers in off-exchange or OTC derivatives, such as swaps. Their motivation, clearly, has been to replace some of their lost banking revenue with the attractive returns that can be earned in derivatives markets. Banks have increased their participation in derivatives markets dramatically in the last few years. In 1994, U.S. banks held derivatives contracts totaling more than $\$ 16$ trillion in notional value. Of these contracts, 63 percent were interest rate derivatives, 35 percent were foreign exchange derivatives, and the remainder was equity and commodity derivatives.

Islamic finance is any finance that operates with the principle of Islamic law (Sharia). It is one of the fastest growing segments of today's banking industry. Ahmed (2010, p.1) argued that the world financial system suffered for too long under conventional (Riba) based banking system. The world in searching for an alternative is "hungry to hear the message loud and clear". Islamic finance is an asset based system. Money in itself has no intrinsic value. The prohibition of paying and receiving fixed, predetermined rate of interest is crucial in Islamic finance. The sale of debt and speculation are not allowed. In the conventional financial system risk is transferred and sold while in Islamic finance it is shared like collective insurance scheme. Ethics and social responsibility are pillars to Islamic finance (Alexakis and Tsikouras, 2009).

Alchaar (2010) pointed that we are facing today a dilemma of compounded greed of individuals, institutions and nation states. Many individuals were trying to buy better houses than they can stand for, institutions who are gambling on the benefit of each other through the creation of credit default swaps and nation states with the laxity of regulation. He states (p.1) 
These macroeconomic imbalances prevailed in the last decade or so resulted in a downward impairment of the term structure of interest rates. This in turn stimulated demand for credit based instruments that achieved the desired yield uplift. It was called "financial innovations". We all believed in the fallacy that these sophisticated tools and instruments would create value. Apparently, the value they created was mostly illusory ... It was a textbook-style manifestation of regulatory sabotage.

The operations of Islamic finance are based on profit-loss sharing principle and risk division in losses and profits between lender and borrower (Mouawad, 2009). World Bank report (2014), argued that country financial system can protect citizens from negative shocks and allowing them to benefit from opportunities. Saving instruments such as bank deposits and credit instruments such as education and mortgages loans can help people to absorb shocks and benefit from opportunities. Banks should match the duration between assets and short term liabilities to make financial system more stable. If the financial system fails to manage risk, it will create loss and damage to people. By making more domestic savings available, hence reducing the effect of foreign capital, more stability and less risk can be achieved. Effective global coordination is necessary for mitigating financial risk. Crises can have impact on long term growth as governments are forced to cut expenditures. The report pointed (p.30):

To better manage the potential for systemic financial crises, countries should establish strong macro-prudential regulatory frameworks-frameworks that consider the interconnectedness of financial institutions and markets and that address the financial system as a whole. Making macro-prudential regulators independent, possibly by placing them under the central bank, is the first step in this direction - as in the Czech Republic, which in 2006 gave the central bank explicit responsibility for fostering financial stability. Governments can then pursue proactive macro prudential supervision and intervene with timely and robust policy tools, as the Republic of Korea did in 2011 in the wake of the international financial crisis by imposing a levy on bank noncore financial liabilities to manage speculative capital flows.

Hersh (2011), pointed to the impact of global financial crises and its deep problem in showing the weakness of global financial system. Global systematic failure created a need for more regulation and unless this is implemented, the world will be more vulnerable to financial crises. Islamic 
finance could be one of the alternatives which can be used to manage risk. She states (p.61):

Islamic finance will not provide a "new way forward," but provides a relevant example of the emergence of a different regulatory system in response to risk created by culturally specific practices .... Risk can never be eliminated, but it can be managed, and policymakers must seek to augment the global financial architecture with a new regulatory framework with a wider scope for institutional differentiation.

The following two sections is going to explain the efforts of Saudi Arabia and Oman in managing two crises and the role played by them. The aim is not to suggest which standards should be implemented in managing risk but to explain real practices that implemented in order to manage financial risk and where capital might have social impact.

\section{Saudi Arabia risk management during Global Financial Crises:}

Risk and economic activities cannot be separated. Risk can be viewed from various levels such as investors, firms and country level also it has various types such as market, operational, and credit risk. In general risk is associated with the uncertainty about various events. To manage risk is to handle it to minimize its impact. Magnusson et al., (2010, p.1) used Basel II (2004) to define operational risk as "the risk of loss resulting from inadequate or failed internal processes, people and systems or from external events". The global financial crises created various doubts about the effectiveness of traditional risk management approaches. It seems that the relevance of risk management was lost. The global financial system failed to prevent the crises and to minimize its impact. When financial crises hit the world, resulting from mortgages all financial institutions as they are mostly, depending on the same financial structure, where in the middle of the avalanche. The risk management strategies and implementation "prove ineffective (or introduce other risks) because they are not coordinated among all relevant policy stakeholders" (World Bank, 2014, p.37). It seems that uniformity in dealing with problems and managing of risk created more deep pain instead of healing it. Most fund managers believe their system and risk management practices were strong and their sand house is too big to fall. The collateralized debt obligations were thought to be safe based on their credit rating. This view failed to account for the fact that the ratings were based on assumptions about default risk, house prices, and cross-correlations among the risks of the underlying assets. The believe, before the crises, is that when storm is coming government interventions will be the financial shield to 
protect corporations and financial institutions. According to World Economic Forum report (2010, p.14)

Prior to the financial crisis, many financial institutions were running similar business and risk management strategies at the product-line level. As evidenced by players' relative performance through the crises, only a few institutions were pursuing a more diversified approach. Indeed, many institutions were simultaneously building large positions in structured credit products derived from the same underlying asset classes, utilizing short-term money-market funding, and making risk management decisions with similar assumptions and techniques. Capital requirements were calculated under similar methodologies, with similar underlying models. Reliance on external credit ratings was pervasive. When the U.S. sub-prime housing bubble burst, financial institutions with the same vulnerabilities all went for the same exit door.

SAMA (2009) forty fifth annual report pointed to many reasons behind the crises including; lack of enough supervision of financial institutions, ease of regulations in financial markets, encouraging securitization and many complicated financial products while underestimating risk inherited in subprime mortgages, decreasing interest rates in U.S. before the crises which created more liquidity that caused real estate to be overvalued and the deficit in the balance of trade. The worldwide recession caused oil and petrochemicals prices to fall and exports of Saudi Arabia to be effected. The global financial crises created liquidity problem worldwide. The global financial system required injection of large amount of cash. Liquidity risks emanate from various financial institutions running out of cash. Banks that finance mortgage-backed securities using repos faced turbulence where "the collapse of the repo market was a calamity" Strahan (2012, p.2). Central banks tried to control the severity of the crises. Puntam (2004, p.31) states:

Liquidity management involves the ability to access capital for emergency purposes in large quantities during difficult and potentially turbulent market conditions ... Central banks need their foreign reserves to be liquid exactly when national markets may be facing broad-based liquidity problems. Whether the cause of the lack of liquidity in national financial markets stems from international pressures on the currency, domestic loan losses in banking portfolios, or from some unexpected national disaster, the central bank must be able to serve as the lender of last resort, thereby supporting the security and stability of the nation's financial system. 
A Senior Supervisors Group report (2008) assessed which risk management practices was effective and which did not, at a sample of eleven global banking organizations and securities firms that are significant competitors during the recent period of financial crises. Some firms were better than others. Those who share quantitative and qualitative information as well as creating a comprehensive understanding among managers team perform better than others. While some institutions were exposed to risk that is above their capacity to tolerate. It was a big failure in controlling and managing risk. They state (p.2)

Another risk management challenge concerned firms' understanding and control over their potential balance sheet growth and liquidity needs. For example, some firms failed to price properly the risk that exposures to certain offbalance-sheet vehicles might need to be funded on the balance sheet precisely when it became difficult or expensive to raise such funds externally. Likewise, some firms found that they could not syndicate their holdings of leveraged loans because of reduced investor appetite for those assets and that they could not cancel their commitments to fund those loans.

The Global Financial Crises of 2007-08 and the European Sovereign Debt Crises created worries about global economic downturn and the need to manage liquidity. The financial markets and capital flows experienced high volatility worldwide as a result of globalization of capital markets. Asset prices and capital flows to emerging market economies effected more strongly than those in advanced economies. As a result of the crises, investors began to focus on safer asset classes and capital flow from riskier countries to advanced economies. Liquidity shocks across countries were effected by exposure to the US and the strength of country fundamentals. Those economies with a poor sovereign rating and worse economic and political institutions were more affected by risk and liquidity shocks in both crises (Chudik and Fratzscher, 2012). Naumoski (2012) argued that investment in emerging economics is difficult due to country risk. Return on investment should be higher in emerging economics compared to developed countries. The period of the Global Financial Crises especially before and at the beginnings were characterized by lack of transparency and the fear of financial institutions to collapse. According to World Economic Forum report (2010, p.27)

Securitization was originally intended to spread risk across the financial system to institutions that were willing and better able to hold the risks. However, when the usage of some structured products "mutated" from their original intent 
(e.g., from risk management to yield enhancement), complexity grew - blurring the boundaries between risk origination and risk ownership and complicating accountability for risk management. Few could understand where the risks truly resided in the system. Packaging complex products as off-balance-sheet, special-purpose vehicles exacerbated the problem, hiding ultimate liabilities from the market. Investors and regulators could no longer discern institutional risk exposure. Moreover, different accounting standards, regional exemptions for capital treatment (e.g., domestic lending portfolios), and a large, less-regulated "shadow banking" sector made it nearly impossible to get a consistent, system-wide view of overall risk.

Chauvin (2010) pointed that Saudi Arabia is the only Middle East Country, the only Arab country among the constituents of the G20. Saudi Arabia is the largest economy of the Gulf Cooperation Council (GCC) including Bahrain, Kuwait, Oman, Qatar, and United Arab Emirates. The Kingdom of Saudi Arabia contributes with $49 \%$ of the total GDP and $67 \%$ of the total population of GCC. Despite the recent financial crisis, the GCC has very important economic developments in the recent years. The increase in oil prices allows GCC countries although not in the same degree to have surplus for building very strong economic positions. Saudi Arabia increased spending in infrastructure, education and health in order to stimulate economic development. According to an IMF study the Saudi fiscal stimulus, valued in $\$ 400$ billon for five years, was the largest in terms of GDP among the members of the G20. The meetings of the G20 accused financial regulators for the global financial crises and focused on increasing borrowing by banks, the unstructured increase of hedge funds and a hunting culture for short-term profits as catalyst of global crises. He states (p.56):

The G20 formalized in Pittsburgh a number of commitments for future regulation of the financial industry, including: increased capital standards; implementing international compensation standards; increasing regulation of the over-thecounter derivatives market; and creating more powerful tools to account for financial risks.

Al-Hamidy (2010) the Vice Governor of Saudi Arabia Monetary Agency (SAMA) pointed that Saudi Arabia did not have to take any measures to support the foreign currency refinancing of banks or corporations. The reason is that Saudi Arabia is a net capital exporter and Saudi banks' asset/liability management is relatively conservative. The SAMA only conducted foreign exchange swaps with domestic banks to 
provide dollar liquidity in order to meet the financial system's demand for foreign exchange. There is an ongoing debate regarding the maximum appropriate amount of foreign exchange reserves. Asian central banks built up their foreign reserves as an insurance policy following the Asian financial crisis in the late 1990s. In fact, this approach helped Asian economies to confront the recent dollar liquidity squeeze. In Saudi Arabia, the foreign reserve position is a reflection of oil market developments and the pattern of government spending. The rate of return on average equity for 2008 was $20 \%$. The high returns in a period of financial crises are a very strong sign of the stability of Saudi banking sector. The financial crisis did not have any impact on the local currency debt market due to the policy followed by the government prior to the crisis to payback its outstanding debt. The corporate bond market was still at infancy stage and was therefore not affected in any way. He states (p.1):

It is important to note that, due to the structure of its economy, its sound economic conditions, prudent and conservative supervisory framework, countercyclical fiscal and banking system policies, and other macroeconomic reasons, Saudi Arabia was not materially affected by the global financial crisis. In fact, while many economies around the globe, especially developed countries, were severely and negatively affected by the crisis in 2008 and 2009, the Saudi economy continued to show resilience and strong economic growth. Consequently, the Saudi Arabian experience of international banking and domestic financial intermediation during this tumultuous period was relatively positive. Although Saudi banks were moderately affected by the deteriorating conditions in the global financial markets, the Saudi domestic financial market continued to function effectively and efficiently without any hiccups.

Ghassan et al., (2013) argued for the mistake of ignoring the interconnectivity in the international financial system which increased the disturbance in financial markets. Saudi Arabia by connecting to U.S. dollar is subject to risk and loss in financial assets. Also most government revenues depend on oil exports which created another risk burden. They use Structural Vector Autoregressive model (SVAR) to assess the impacts of international financial crisis on real economic growth although the impact of financial crises on Saudi Arabia is limited. They state (p.404):

Considering the asymmetric SVAR, the accumulated response of GDP to a structural one standard deviation shock indicates that the effect of international liquidity shocks on GDP is enough gradual, taking number of years to arrive at its full level. The full effect of positive shock is about 
$1.01 \%$ increase in the real economic growth leading to a positive dynamic pass-through elasticity of 0.032 , where as the negative shock droves to reduce the economic growth by $1.04 \%$ driving to a negative dynamic pass-through elasticity of 0.070 .

Williams (2004) highlighted the need of cash management for governments which was not emphasized like credit management. Cash management can be seen as strategy by which governments manage short term cash flows and cash balances. Governments must be able to meet its obligations and finance its expenditure. The success by government to reduce operating, credit and market risk is an objective of efficient cash management. Khamis et al., (2010) pointed to the differences between Gulf countries in their effect and response to the global financial crises. After Lehman's, the financial sector in United Arab Emirates (U.A.E.), Kuwait, and Bahrain were effected more than Saudi Arabia. The increase in government spending in Saudi Arabia was a defense against the crises. Thanks to increase of reserves resulted from increasing oil prices before the financial crises. They state (p.16):

Banks' capital adequacy ratios remain strong and there are positive indications on profitability. The GCC financial systems entered the global crisis from a position of strength, with high capital adequacy and modest NPLs. Despite the general increase in NPLs in 2009, banks' capital adequacy remains high, supported by injections of public funds in Qatar and the U.A.E., and private capital in Kuwait and Saudi Arabia.

The financial sector management in Saudi Arabia was very successful during the financial crises. Interest rates were cut by a cumulative 350 bps to 2 percent between October 2008 and January 2009 also reserve requirements on demand deposits were cut by a cumulative $600 \mathrm{bps}$ in October and November 2008. The government ensures that deposits in local banks are guaranteed. Also, depositing huge amount of cash in banks on behalf of government organizations. Government credit institutions are provided with SAR 40 billion during 2009. The resources of the Real Estate Development Fund have been enhanced by an amount of SAR 25 billion to be equally distributed over five fiscal years as from fiscal year 2008 to meet the demand for housing loans. The Saudi Credit and Saving Bank has allocated an amount of SAR 10 billion to give loans to low income citizens, including social loans, professional loans and auto loans. The Public Investment Fund has increased the ceiling of lending from 30percent to 40 percent of the cost of investment projects, and maturities from 15 to 20 years 
to facilitate the process of financing projects (SAMA, 2009).According to International Monetary Fund (2012, p.5) report:

In particular, the Saudi Arabian Monetary Agency (SAMA) introduced Basel II, and used Pillar 2 requirements to foster improvements in banks' risk management and capital planning. In supervision, risk-based approaches (RBAs) have been introduced. SAMA has also been active in introducing the new Basel III requirements. The Capital Market Authority (CMA) has developed a strong regulatory program in a short period of time that fully implements most international standards.

The World Economic Forum report (2010, p.31) pointed to the increase complexity in the real world that require more comprehensive and overall view of the system with the interdependence between its subsystems. The models of risk management that "utilize idealized linear, stable equilibrium dynamics" cannot fit financial crises that consists of "a complex web of interacting parts that are fundamentally nonlinear - i.e., nonequilibrium, unstable, and non-stationary - in their dynamic behavior". Regulators need to critically examine and analyze the comprehensive effects of any financial product on society, identifying potential risk and the interactions between products on the markets.

\section{Oman risk management during oil prices shock:}

Oman economy is greatly dependent on its oil and gas sector returns. In fact, reliance entirely on one industry to build economic development would be as a serious setback, in case of falling price or production. Devaux (2013) stated that since 1990, hydrocarbons exports marks a notable drop as it has dropped from $90 \%$ reached to $65 \%$ of the total exports,. In return, Omani private industry has contributed about $70 \%$ of non-oil GDP. Notwithstanding that, the revenues of Oil have decreased for the past two decades; the Omani economy is still built on this industry. CBO (2014) indicated in the 2013 annual report that oil and gas industry accounts for around $75 \%$ of government revenues. Consequently, private sector in Oman is unable to support economic and feed development. Recently, after the oil price falling down, Oman government has two choices no more that are reduction in expenditures or cut subsidies.

In spite of the global economic growth anticipation for 2014 has been marked down by $0.3 \%$ to $3.4 \%$, the World Economic Outlook predicted that the growth will increases up to $5.2 \%$ in 2015 from its reduction at $4.6 \%$ in 2014in the emerging and developing economies (International Monetary Fund (IMF), 2014) see Table 1.This is likely because of the improvements in accelerated fiscal and support activity, tax relief and more spending in 
infrastructure. In response to the robust growth in services sector activities in Oman, the GDP at market prices has rose to $4.6 \%$ in the first quarter of 2014 , and is expected to grow in 2015.This reflects that whenever economic activities improve, the capability of Oman economy could offer a better standard of living to the community.

Table 1: Economic growth predictions

Economies 2014

2015

Growth by

\begin{tabular}{c|ccc} 
World & $3.4 \%$ & $4.0 \%$ & $0.6 \%$ \\
Advanced & $1.8 \%$ & $2.4 \%$ & $0.6 \%$ \\
Emerging & $4.6 \%$ & $5.2 \%$ & $0.6 \%$ \\
Middle East & & & \\
Oman & $3.1 \%$ & $4.8 \%$ & $1.7 \%$ \\
\end{tabular}

Source: IMF, (2014)

The role of financial industry cannot be ignored in thriving economy, as it is a means and the source of funding to various activities and sectors. The Sultanate's has 20 banks constitute the banking sector, which include two local Islamic banks, seven commercial banks, two specialised banks, and nine foreign banks. Moreover, it has six local commercial banks providing windows that operate Islamic banking services (CBO, 2014).This actually diversify the productivity of these banks with a competition atmosphere and revival the financial sector in Oman. The annual report shows an increase of the aggregate deposits by commercial banks reaching to OMR 15.6 billion in 2013 compared to OMR 14.2 billion for 2012 (CBO, 2014). According to the Moody's Investors Service, the outlook of Oman's financial industry is stable, and in 2014 is expected to grow about $10 \%-12 \%$ in constant conditions of macroeconomic (Moody's Investors Service, 2014). Therefore, their strong performance remains stable due to their total assets growth (see Figure 1).

Figure 1: Strength of assets, aggregate deposits, and credit of commercial banks in Oman 


\section{Financial System Composition in Oman 2013}

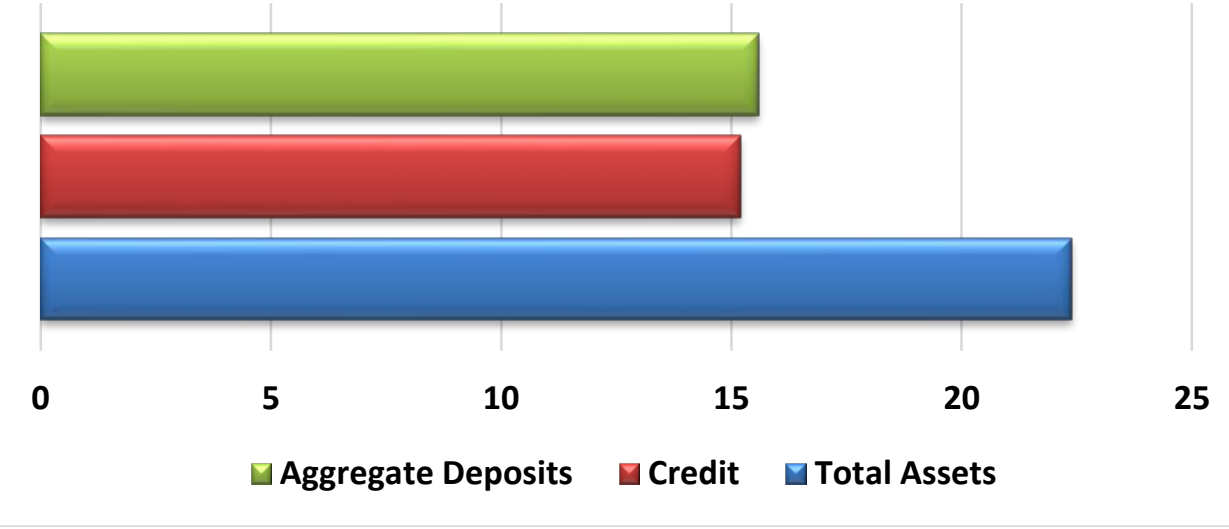

Source: The Annual Report 2013 (CBO, 2014).

Unemployment rate is a critical indicator in the economy that could heading into recession whenever raised and then workers will cost industries more. According to the Ministry of Civil Service (MoCS), in 2013 about $89.3 \%$ of the total labour force in Omani private sector $(1,709,101)$ are expatriates employees about 1,527,241, where Omanis employees constitute $10.7 \%$ only around 181,860 (CBO, 2014). This fact has led to re-examine the functional status in Oman, particularly in the private industry.

Table 2: Employment in Oman by public and private sectors (end of 2013)

\begin{tabular}{c|ccccc}
\multicolumn{1}{c}{2009} & 2010 & 2011 & 2012 & 2013 \\
\hline Private Sector Employees1 & $1,032,560$ & $1,133,346$ & $1,289,031$ & $1,488,248$ & $1,709,101$ \\
Omanis & 158,315 & 177,716 & 174,441 & 172,066 & 181,860 \\
Expatriates & 874,245 & 955,630 & $1,114,590$ & $1,316,182$ & $1,527,241$ \\
Public Sector Employees2 & 126,134 & 128,415 & 144,605 & 151,683 & 166,707 \\
Omanis & 111,845 & 114,206 & 129,107 & 134,417 & 145,736 \\
Expatriates & 14,289 & 14,209 & 15,498 & 17,266 & 20,971
\end{tabular}

1. The Annual Report 2013 (CBO, 2014) - Private Sector Employees.

2. The Annual Statistics of Civil Service Employees 2013 (Ministry of Commerce and Industary , 2014)- Public Sector Employees.

Obviously, that expatriates dominate the labour force in the private sector as it is outlined in Table 2. In Addition, it clarifies that $10.7 \%$ of the labour force were not SMEs owners, which implies that their contributing into GDP were not significantly as should. Let alone that the number of Omanis employees in the private industry has increased by $5 \%$, while expatriate employees increased by about $14 \%$ in 2013. As a result, the 
government believes that creating jobs would be through expanding investment and enhancing and financing SMEs.

Through creating opportunities outside the public sector, SMEs play a developmental role in developing an economy. Where the most successful SMEs would become large private enterprises and thereby its prosperity can benefit the whole of society as well as redound positively on the GDP and employment rate in the country. According to the Public Authority for SME Development (PASMED) (2014), about 132,735 SMEs distributed in Omani governorates involving a variety of trading activities and that represent more than $90 \%$ of all corporate; these materialising a vital social position for the private sector. Based on Oxford Business Group Report in 2013, SMEs in Oman constitute about $16 \%$ of GDP, which is no small feat compared to others such as firms in OECD and Europe that achieved 51\% and 58\%, respectively.

The acting CEO of PASMED in Oman, Khalifa Al Abri, has confessed that although SMEs are the significant component in the private industry; however, the active SMEs in Oman did not reach half the number that raised in the private sector and are even less those being operated and managed by Omanis. This means that Oman's SMEs currently are not performing their function properly. This showed in Table 3 below as the ranking of contributions to GDP, Oman's SMEs at the tail end of the rankings associated with Qatar compared to other GCC's SME. Therefore, Khalifa has mentioned that over the next five years SMEs have to increase their GDP contribution to about 20\%. Through providing support in marketing, developing business plans, training, design, and products packaging; this aim could be achieved (Muscat Daily, 2013). It is expected that this would create more jobs, and increase productivity and innovation rather than just selling and buying of imported goods and services.

Table 3: in 2013, Oman has low percentage of GDP and employment contributed by SMEs in GCC

Countries Contributions to GDP

Contributions to Employment

\begin{tabular}{c|c|c|}
\hline Kuwait & N/A & $45 \%$ \\
\hline United Emirates & $35 \%$ & $86 \%$ \\
\hline Saudi Arabia & $33 \%$ & $40 \%$ \\
\hline Bahrain & $28 \%$ & $73 \%$ \\
\hline Oman & $16 \%$ & $20 \%$ \\
\hline Qatar & $10 \%$ & $15 \%$ \\
\hline
\end{tabular}

Sources: CBO: Annual Report 2013; Devaux 2013; and GICWED 2013. 
Accordingly, enhancing and developing SMEs were the main priority that made by the government of Oman in order to create more job opportunities and boost innovation. This would reduce the highest official unemployment rate of Oman which reach up to $15 \%$ compared to other GCC countries in 2011 (Devaux, 2013).Consequently, government has enacted comprehensive strategies that would prosper the private sector. For example, launching a guarantee programme, in which about $50 \%$ of Oman's SMEs loans will be granted (PASMED, 2014). Furthermore, the Sanad programme that in addition to offer soft loan with $2 \%$ interest rate, it provides a mentorship and assistance with government services (Oxford Business Group Report, 2013). Adding to this, the Al Rafd Fund is founded to support entrepreneurs in their venture, as a means to stimulate the private sector to thrive. SMEs projects could also be financed through providing about OMR 5.4 million by the Oman Development Bank (ODB) .On the other hand, the Public Authority for Investment Promotion and Export Development (PAIPED) has been established in attempting to assist SMEs extensively to promote their investment abroad. Nonetheless, banking industry remains the official and main source of any investment venture to ensure its needs in cash flow and capital.

Certainly, the growth and development of the banking sector has a vital aspect in the prosperity of the economy where there a great linking between them and thus vulnerable to the effect of the movement of the banking sector. Accordingly, this sector should be regulated with special care with caution to design a competitive atmosphere and an appropriate financial system to achieve a high positive economic performance. For instance, Oman's banks have been directed by the Central Bank of Oman (CBO) to extend loans and credit facilities to SMEs through earmarking at least 5\% of their total credit portfolio (CBO, 2013). This demonstrates that both the private and public institutions have made concerted efforts to reinforce the economic growth and thereby provide a secure future for people.

In fact, banking industry is lasting source to enhance the development of various economic industry through grants some financial facilities to the small investors such as an interest-free loan, like that being given by ODB as for an amount of OMR 5,000 (ODB, 2011). Bank Muscat (BM) has also launched a programme called " $\boldsymbol{A l}$ Wathbah", in which SMEs get financial and advisory services. It also provides up to OMR 400,000 for financing small firms and for the medium firms up to one million, subject to certain requirements that stipulated by the bank (BM, 2014). Recently, Oman has introduced Islamic banking services in order to expand economy due to its vital role in SMEs development. Therefore, it is timely to investigate over banking practices, specifically those enacted in diversifying economy. Particularly, those initiatives provided by the banking sector incorporate 
financial operations that actively lead to SMEs development and thereby economic prosperity.

Undoubtedly, that there are obstacles of a similar nature suffered by SMEs around the globe, not to mention the existence of obstacles based on the geographical and cultural aspects of each country. Consequently, this will hinder SMEs from doing its development role to contribute in promoting job creation and GDP. Generally, SMEs, as discussed above, contribute around $60 \%$ to GDP and just over that figure to employment. However, SMEs in Oman are contributed less than the above average, with just $20 \%$ to employment and $16 \%$ to GDP (CBO, 2014). Parambi (2014a) attributed this to the; lack of realism in expectations by young entrepreneurs, Lack of professionalism in business administration, Lack of appropriate funding mechanisms, excessive cost of capital and debt, and Low tolerance thresholds. PASMED (2014) also intimated that in addition to that SMEs in Oman lie in the difficulties of; infrastructure weakness, lack of appropriate marketing strategies, linkage development requirement with large industries, and complying with the national strategies and policies.

In spite of incentive support provided to SMEs by the Oman government, however the failure rate of Omani SMEs remains far from the ambition. This could mainly imputed to the efforts that often on providing financing and in some cases trainings rather than investment opportunities. Moreover, this alarming failure of SMEs in Oman attributed to; legal procedures, a perceived lack of entrepreneurial qualities, scarcity of raw materials, and large-scale projects competition (Ayoob and Somasundaram, 2012).This confirmed that funding is not the only obstacle in Oman rather a lack of management and efficiency on entrepreneurial skills as an example. Let alone, the overly bureaucratic regulations that depress the ability to fight and rival the large companies (PASMED, 2014 \& Parambi, 2014b).

Compared to other GCC countries, Oman has smaller reserves of Oil and still relies heavily on it for its strategies development since the beginning of renaissance in 1970. Controversy and concern among citizens now in the midst of the low price of a barrel of oil, and the absence of another source as an alternative for decades ago. Partly because Oman has focused on its development to the Oil source income solely although it is more vulnerable to influencing of falling oil prices and in 2013 total reserves were estimated at 5.15 billion barrels, meaning that Oman has low rate of oil reserves and not lasting. The IMF pointed out that Oman's "break-even" oil price - the level required to balance its budget - would rise from $\$ 62$ in 2008 to a projected $\$ 120$ in 2018. Therefore, the priority is to rationalise the government revenues sources and find alternative sources in order to ensure sustainability and to reform the prevailing fiscal policy. As the continuous 
fiscal policy expansion in the presence of certain finite nature of resources may lead to sustainability challenges at the end and for long time.

This warning Oman government over its expansionary spending since 2011, with a significant reliance on oil revenue and small portion on non-oil sector. In this regard, IMF has echoed that Oman need to contain government spending and must increase its revenues through non-oil industry in order to keep its finances sustainable due to the expectation of widening deficit as much as $6.8 \%$ of GDP by 2018. Adding that without mainly changing subsidies on fuel, Oman would facing difficulties to place its state finances on a sustainable footing and it should raises its domestic fuel prices gradually.In the absence of alternative sources to support government expenditures, Oman may not be able to encounter the challenges ahead due to fluctuations in the price of oil especially that seen in 2014 from the sharp decline on oil barrel price. According to the CBO (annual report 2013), government participation and other expenses accounting to over 2 billion in 2013 with an increase of $8 \%$ from the year 2012,of which 54.6\% to support petroleum products. As a result, it can be said that although revenue and income resulting from the oil sector, but it consumes more than $50 \%$ of government expenditures for oil extraction project.

Recently, after the falling of oil price down, Oman government announced that the lower price of a barrel of oil would confronted by the ceasing of recruitment and promotions. This was expected after it has proclaimed that the short-term objective for government is to decrease 9\% of the oil sector's contribution to overall GDP by 2020 and thus enhances creating more job opportunities in the private rather than public sector (CIA, 2014).This is compatible with the ultimate goal in decreasing pressure on oil revenues, as it constitutes a large burden by the state employment. In this matter, His Majesty Sultan Qaboos has called to the expansion of the significant efforts that would reinforce productivity of SMEs and entrepreneurship. 
Figure 1: Share in GDP at current market price

\section{Gross Domestic Product at Current Market Prices \\ (Rial Omani Million)}

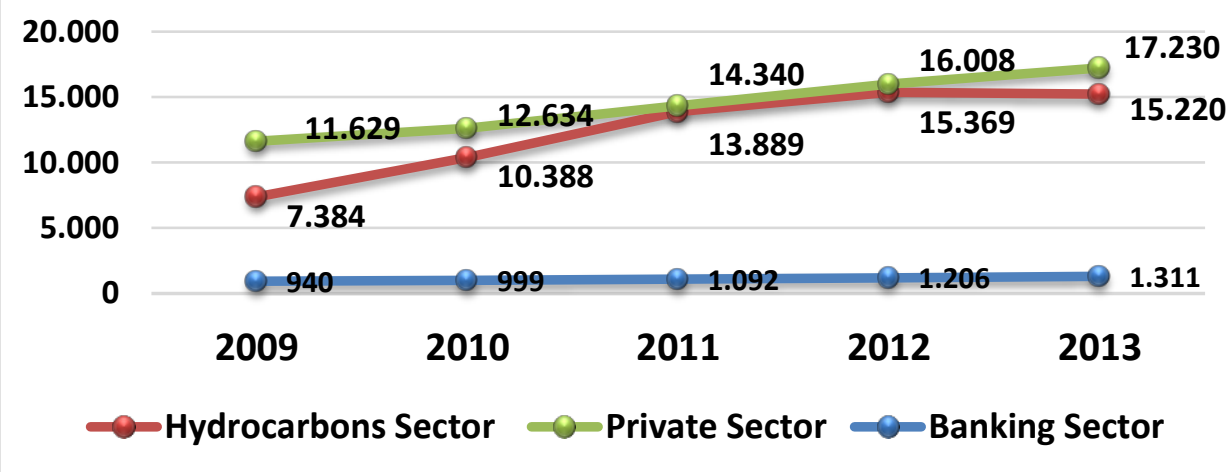

Source: NCSI, (2014).

According to the National Centre for Statistics and Information (NCSI) (2014), in 2013 the petroleum industry activities have witnessed a fall to OMR 15,220 million, compared to OMR 15,678 million in 2012. In contrast, other sectors' activities had grown by $7.6 \%$ from OMR 16,008 million in 2012 to OMR 17,229 million by the end of 2013. This suggests that the private sector should fill the income gap created by the oil price oscillation. The International Monetary Fund (IMF) World Economic Outlook forecasts of the global economy were projected to be slightly higher in 2014 witnessing an increase of $0.6 \%$ to reach $3.6 \%$ from 3\% in 2013 . Specifically, emerging and developing economies are predicted to witness a gradual rise of $0.2 \%$ up to $4.9 \%$ from $4.7 \%$ in 2013 (IMF, 2014); see Table 1. This is likely due to the improvements in domestic demand, large public expenditure, and more investment spending. In Oman, the GDP growth rate was about $2.8 \%$ in 2013, which rose to $4.6 \%$ in the first quarter of 2014 (NCSI, 2014), with a position of 77 in the world (CIA, 2014). This reflects that the capacity of Omani society could offer a better standard of living with improved economic activity.

Table 4: Economic growth rate

Economies 2013
2014
Growth by

\begin{tabular}{c|ccc} 
Global & $3 \%$ & $3.6 \%$ & $0.6 \%$ \\
Emerging & $4.7 \%$ & $4.9 \%$ & $0.2 \%$ \\
Oman & $2.8 \%$ & $4.6 \%$ & $1.8 \%$
\end{tabular}

Sources: NCSI, 2014; CBO, 2014. 
The financial sector in Oman is a very important industry leading the sources of funding and financial transactions for other sectors. According to the 2013 annual report, it comprises 20 banks including seven local commercial banks, nine foreign banks, two specialised banks, and has recently added two fully-fledged Islamic banks together with six local commercial banks operating separate Islamic windows for banking operations (CBO, 2014), creating diversity of products, ability for competition and market resuscitation in Omani banking. Moody's Investors Service (2014) set forth the outlook for Oman's banking system as stable, and with the stability of macroeconomic conditions, the credit is forecast to grow around 10\%-12\% in nominal terms in 2014. Moreover, the 2013 annual report indicates that commercial banks registered increase in aggregate deposits amounting to OMR 15.6 billion in 2013 from OMR 14.2 billion for the year before (CBO, 2014). Therefore, their performance has continued to remain strong and favourable due to robust growth and increases of their total assets (see Figure 3).

Figure 2: Strength of assets, aggregate deposits, and credit of commercial banks in Oman

\section{Financial System Composition in Oman 2013}

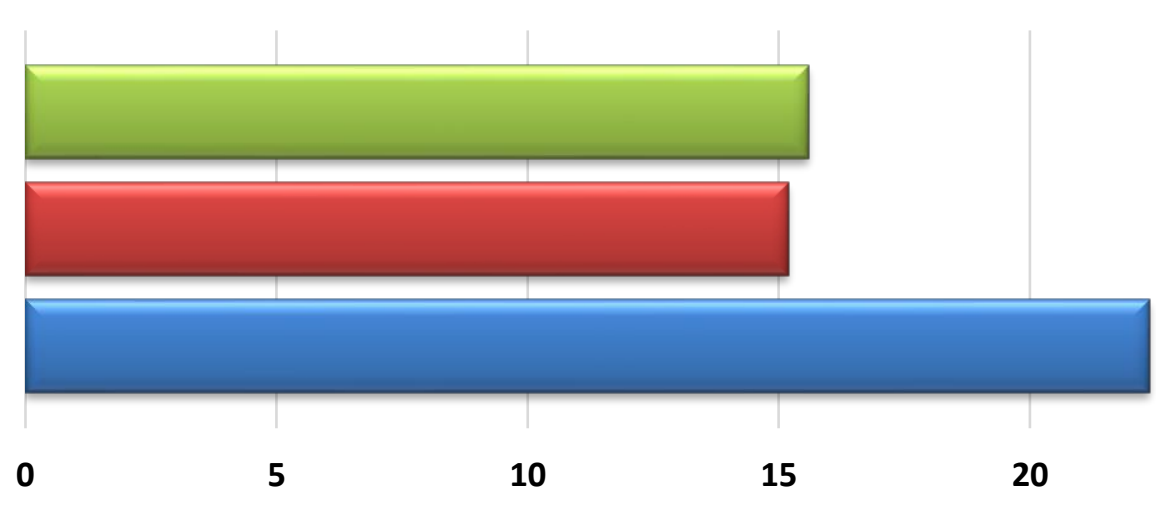

$\square$ Aggregate Deposits $\square$ Credit $\square$ Total Assets

Source: The Annual Report 2013 (CBO, 2014).

An increase in the unemployment rate means that economic conditions are heading into recession and industries have to make people redundant. It is an important indicator of the health of an economy and signifies which sectors are creating or losing jobs. According to the annual statistics of civil service employees published by Oman's Ministry of Civil 
Service (MOCS), the total number of public sector employees at the end of 2013 was 166,707; of which, 145,736 were Omanis, and 20,971 were expatriates, representing $87.4 \%$ and $12.6 \%$ respectively. Whereas, the total labour force of the private sector was $1,709,101$ in 2013, of which 181,860 were Omanis - representing approximately $10.7 \%$ - and 1,527,241 were expatriates - representing about $89.3 \%$ (CBO, 2014). These figures have led to calls to re-examine and study the functional status in the Sultanate, especially in the private sector.

Table 5: Employment in Oman by public and private sectors (end of 2013)

\begin{tabular}{|c|c|c|c|c|c|}
\hline & 2009 & 2010 & 2011 & 2012 & 2013 \\
\hline Private Sector Employees ${ }^{1}$ & $1,032,560$ & $1,133,346$ & $1,289,031$ & $1,488,248$ & $1,709,101$ \\
\hline Omanis & 158,315 & 177,716 & 174,441 & 172,066 & 181,860 \\
\hline Expatriates & 874,245 & 955,630 & $1,114,590$ & $1,316,182$ & $1,527,241$ \\
\hline Public Sector Employees ${ }^{2}$ & 126,134 & 128,415 & 144,605 & 151,683 & 166,707 \\
\hline Omanis & 111,845 & 114,206 & 129,107 & 134,417 & 145,736 \\
\hline Expatriates & 14,289 & 14,209 & 15,498 & 17,266 & 20,971 \\
\hline
\end{tabular}

1. The Annual Report 2013 (CBO, 2014) - Private Sector Employees.

2. The Annual Statistics of Civil Service Employees 2013 (MOCS) Public Sector Employees.

Table 2 outlines that the private sector was dominated by expatriates. This also clarifies that 181,860 Omani employees in 2013 were not owners of the SMEs and were just employees; the implication is that they are not contributing significantly to GDP compared to other emerging economies. In 2013, expatriate employees increased by about 14\%, while Omanis employees increased by 5\% only. Many now believe that the government needs to show mettle in creating jobs through enhancing and financing SMEs and expanding investment. CIA (2014) proclaimed that Oman is too heavily dependent on dwindling oil resources; the short-term objective is to reduce the oil sector's contribution to overall GDP by up to $9 \%$ by 2020 and thereby creating more job opportunities for the younger Omani generations. Accordingly, the His Majesty Sultan Qaboos has made widely reported statements indicating the need for the support of other sectors to be sustainable, and has called for expanded efforts to foster SMEs and entrepreneurship, as state employment is becoming a burden in the light of decreasing oil revenues in the future. 


\section{Conclusion:}

The global financial crises as a general epidemic created various doubts about the effectiveness of traditional risk management approaches. Also as most Arab countries are relying on crude oil prices to finance their budgets, they are under great risk due to decreasing oil prices. Risk management during time of turbulence must be effective to avoid, control or mitigate risk. Traditional finance and Islamic finance have different approaches in dealing with risk. By giving two examples of Islamic countries-Saudi Arabia and Oman- dealing with financial shocks, this chapter aimed to contribute to the understanding of managing risk in emerging economics in two particular Arab Countries who behave differently during time of turbulence.

\section{References:}

Ahmed, F. (2010)., The Future of Islamic Banking and Finance in the GCC and the world, Opinion Column, Accessed on 12th December at http://www.opalesque.com/OIFI143/Opinion_Column_The_Future_of_Isla mic_Banking_and43 html.

Alchaar, M. (2010)., Chairman"s Speech: Euromoney"s 9th Annual Islamic Summit, Accounting and Auditing Organization for Islamic Financial Institutions, London, February 23, Accessed on 15th December 2011 at http://www.aaoifi.com/AAOIFI\%20-

$\% 20$ Euromoney\%20\%20Speech\%20by\%20Dr\%20M\%20N\%20Alchaar.pdf.

Alexakis, C. and Tsikouras, A. (2009)., Islamic Finance: Regulatory Framework Challenges Lying Ahead, International Journal of Islamic and Middle Eastern Finance and Management, Volume. 2, No.2, 2009, pp.90104.

Al-Hamidy, A. (2010)., The global financial crisis: impact on Saudi Arabia, Bank for International Settlements (BIS), No.45, http://www.bis.org/publ/bppdf/bispap54u.pdf, Accessed 19/01/2015.

Ayoob, P, and Somasundaram, B. (2012)., SMEs in Sultanate of Oman: Meeting the development challenges, The International Journal: Research Journal of Economics \& Business Studies, Volume 1, No. 9, pp. 27 30,https://www.theinternationaljournal.org/ojs/index.php?journal=rjebs\&pag $\mathrm{e}=$ article\&op=view\&path\%5B\%5D=1006, Accessed 22 June 2014.

BM, (2014), Al Wathbah., http://www.bankmuscat.com/en-us/AlWathbah/termloan/Pages/default.aspx, Bank Muscat, Accessed 6 April 2014. CBO, (2013)., Small and Medium Enterprises (SMEs), http://www.cbooman.org/circulars/2013/BM1108SME.pdf , Central Bank of Oman, Circular BM1108, Accessed 21 June 2014. 
CBO, (2014)., Annual Report 2013 Muscat: CBO, http://www.cbooman.org/annual/CBOAnnualReportEN2014.pdf, Central Bank of Oman, Accessed 05 July 2014.

Chauvin , (2010), The Rise of the Gulf: Saudi Arabia as a Global Player, International Reports, http://www.kas.de/wf/en/33.19450/, Accessed 07January2015.

Chudik, A. and Fratzscher, M. (2012)., Liquidity, Risk and the Global Transmission of the 2007-08 Financial Crises and the 2010-11Sovergien Debt Crises, European Central Bank (ECB), Working Paper Serious No.1416, pp.1-46.

CIA, (2014)., The World Fact Book: Oman, Economy Overview, Central Intelligence Agency,https://www.cia.gov/library/publications/the-worldfactbook/geos/mu.html - Accessed 22 June 2014.

Devaux, P. (2013)., 'Economic diversification in the GCC: Dynamic Drive needs to be Confirmed', BNP PARIBAS: Economic Research, pp. 17-25, http://economicresearch.bnpparibas.com/Views/DisplayPublication.aspx?typ $\mathrm{e}=$ document\&IdPdf=22570, Accessed 05 July 2014.

Edwards, F. and Mishkin F. (1995)., The Decline of Traditional Banking: Implications for Financial Stability and Regulatory Policy, Federal Reserve Bank of New York, Economic Policy Review, Vol. 1, No.2, pp. 27-45.

Gait, A. and Worthington, AC. (2007)., Primer on Islamic Finance: Definitions, Sources, Principles and Methods, University of Wollongong, School of Accounting and Finance, Working Paper Series No. 07/05.

Ghassan, H. Alhajhoj, H and Kbiri Alaoui, M. (2013)., The Impacts of International Financial Crisis on Saudi Arabia Economy: Evidence from Asymmetric SVAR Modelling, Journal of Reviews on Global Economics, Volume. 2, pp.390-406.

GICWED, (2013)., Gulf Investment Corporation, Weekly Economic Digest, Volume, 109, No.3, pp. 1-3, https://www.gic.com.kw/site_media/GICGADES/GICWED109a.pdf, Accessed 11 July 2014.

Hersh, E. (2011)., Islamic Finance and International Financial Regulation, Journal of International Service, Spring, pp.51-64.

International Monetary Fund, (2012)., Saudi Arabia: Financial System Stability Assessment-Update, IMF Country Report No. 12/92, International Monetary Fund Washington, D.C.

IMF (2014)., World Economic Outlook (WEO) Recovery Strengthens, Remains Uneven: World Economic and Financial Surveys, International Monetary Fund , http://www.imf.org/external/pubs/ft/weo/2014/01/, Accessed 05 July 2014.

Ingham, B. (2008)., International Economics a European Focus, Financial Times Prentice Hall. 
Kaufman, G. (2000)., Banking and currency crises and systemic risk: Lessons from recent events, Financial Markets, Institutions, and Instruments, Volume. 9, No. 2, pp.9-28.

Khamis, M. Senhadji, A. Charap, J and Cevik, S. (2010)., Impact of the Global Financial Crisis on the Gulf Cooperation Council Countries and Challenges Ahead: An Update, http://www.imf.org/external/pubs/ft/dp/2010/dp1002.pdf, Accessed 21 June 2014.

Khan, T. and Ahmed, H., (2001), Risk Management: An Analysis of Issues in Islamic Financial Industry, Islamic Development Bank, Jeddah, Saudi Arabia.

Magnusson, T. Prasad, A. and Storkey. (2010)., Guidance for Operational Risk Management in Government Debt Management, International Bank for Reconstruction and Development, http://treasury.worldbank.org/bdm/pdf/Guidance_OperationalRiskManageme nt_Mar2010_Magnusson.pdf, Accessed 15/01/2015.

Ministry of Commerce and Industry (2014)., Small and Medium Enterprises (SME),http://www.mocioman.gov.om/Main-Menu/Business-Services/Smalland-medium-enterprises.aspx , Accessed 20 June 2014.

Mishkin, F.S. (2012)., The Economics of Money, Banking and Financial Markets (Ninth Edition), Pearson, Global Edtion.

Moody's Investors Service (2014)., Moody's says Oman's banking system outlook remains stable: Global Credit Research, https://www.moodys.com/research/Moodys-says-Omans-banking-systemoutlook-remains-stable--PR_293078, Accessed 20 June 2014.

Mouawad, S. (2009)., The Development of Islamic Finance: Egypt as a Case Study, Journal of Money Laundering Control, Volume.12, No.1, pp.74-87.

Muscat Daily staff writer (2013)., SMEs, the Engines of Economic Growth'. December $09 . \quad$ Muscat Daily.com, http://www.muscatdaily.com/Archive/Business/SMEs-the-engines-ofeconomic-growth-2rl4, Accessed 21 June 2014.

NCSI, (2014)., Economic Review 2013: Fourth Quarter Muscat, National Centre for Statistics and Information http://www.ncsi.gov.om/NCSI_website/PublicationAttachment/eng\%20ECO NOMIC\%20REVIEW\%20Q4\%20Abril\%202014\%20.pdf - Accessed 20 June 2014.

Numoski, A., (2012)., Estimating the Country Risk Premium in Emerging Markets: The case of the Republic of Macedonia, Financial Theory and Practice, Volume. 36, No.4, pp. 413-434.

ODB, (2011)., Oman Development Bank (ODB),http://www.odb.com.om/DevelopmentLoans.aspx, Accessed 5 April 2014. 
Oxford Business Group, (2013)., Small but mighty: Financing and other Services Expand to Support SMEs, http://www.oxfordbusinessgroup.com/news/small-mighty-financing-andother-services-expand-support-smes , Accessed 20 June 2014.

Parambi, R. (2014a)., Omani Small and Medium Enterprises Facing Tremendous Challenges: CEO National Company for Projects and Management, Times of Oman, 16 February, http://www.timesofoman.com/News/Article-29882.aspx\# , Accessed 12 July 2014.

Parambi, R. (2014b)., SME development in Oman: Case of the Missing Middle', Oman Observer, February 02, http://main.omanobserver.om/?p=53293 - Accessed 20 June 2014.

PASMED, (2014)., The Final Book' Report of SMEs, The Public Authority for Small and Medium Enterprises Development, http://omansme.gov.om/?lang=en-US , Accessed 3 April 2014.

Puntam, B. (2004)., Thoughts on Investment guidelines for Institutions with special Liquidity and Capital Preservations Requirements, European Central Bank,https://www.ecb.europa.eu/pub/pdf/other/riskmanagecbreserves2004en .pdf, Accessed 19/01/2015.

Rowey, K. , July, C. and Fevre, M., (2006)., Islamic Finance: Basic principles and structures; A focus on Project Finance, Freshfields Bruckhaus Deringer.

SAMA, (2009)., Forty Fifth Annual Report: The Latest Economic Developments, Saudi Arabian Monetary Agency, http://www.sama.gov.sa/sites/samaen/ReportsStatistics/ReportsStatisticsLib/ 5600_R_Annual_En_48_2013_02_19.pdf, Accessed 20/01/2015. SEC, (2015)., Investor Bullet: In What Are Corporate Bonds?, U.S. Security Exchange http://www.sec.gov/investor/alerts/ib_corporatebonds.pdf,

Committee, $12 / 01 / 2015$

Senior Supervisors Group, (2008)., Observations on Risk Management Practices during the Recent Market Turbulence, http://www.newyorkfed.org/newsevents/news/banking/2008/SSG_Risk_Mgt _doc_final.pdf, Accessed 20/01/2015.

Strahan, P. (2012)., Liquidity Risk and Credit in the Financial Crisis, FRBSF Economic Letter, http://www.frbsf.org/economicresearch/publications/economic-letter/2012/may/liquidity-risk-creditfinancial-crisis/, Accessed 19/01/2015.

Williams, M., (2004), Government Cash Managment Good -and Bad Practice, http://treasury.worldbank.org/bdm/pdf/CM-V2Aug04MikeWilliams.pdf, Accessed 19/01/2015. 
World Bank, (2014)., World Development Report: Risk and Opportunity Managing Risk for Development, http://siteresources.worldbank.org/EXTNWDR2013/Resources/82580241352909193861/8936935-1356011448215/8986901-1380046989056/WDR2014_Complete_Report.pdf, Accessed 18/01/2015.

World Economic Forum, (2010)., Rethinking Risk Management in Financial Services Practices from Other Domains, Boston Consulting Group, http://www.weforum.org/pdf/FinancialInstitutions/RethinkingRiskManagem ent.pdf, Accessed 22/01/2015.

Zerban, A. Elkady, E. and Omar, R. (2012)., Islamic Finance and Global Financial Crises: How to Keep Finance on Track?,Topics in Middle Eastern and African Economies, September, Volume.14, pp.199-222. 